\title{
The Impact of Enhanced Teammate Evaluations on Important Individual and Team Outcomes
}

\author{
Erik R. Eddy ${ }^{1}$, Caroline P. D’Abate ${ }^{2} \&$ Melinda Costello ${ }^{1}$ \\ ${ }^{1}$ Management Department, Siena College, Loudonville, NY, USA \\ ${ }^{2}$ Department of Management \& Business, Skidmore College, Saratoga Springs, NY, USA \\ Correspondence: Erik R. Eddy, Management Department, Siena College, 515 Loudon Road, Loudonville, NY \\ 12211, USA. Tel: 1-(518)-782-6761. E-mail: eeddy@siena.edu
}

\author{
Received: September 22, 2019 Accepted: October 17, 2019 Online Published: October 21, 2019 \\ doi:10.5539/jedp.v9n2p158 \\ URL: http://doi.org/10.5539/jedp.v9n2p158
}

\begin{abstract}
There is evidence that teamwork is proliferating in organizations and, in many ways, is replacing working individually. Academia has responded by integrating teamwork into curricula, but the use of teams as a pedagogical approach is also driven by evidence that it can lead to enhanced learning and more engaged learners. Researchers have examined factors in team effectiveness, activities and assignments for student teams, and ways to optimize team formation. The current study was designed to focus on an under-explored and critical area of managing teamwork in classroom pedagogy: peer feedback. Students were placed into two conditions - a "conventional" approach using general, non-benchmarked feedback and an "enhanced" behaviorally-specific, benchmarked approach. Findings suggest enhanced teammate evaluations held substantial benefits over conventional evaluations resulting in better student perceptions of team processes (i.e., action, transition, and interpersonal processes) as well as more enthusiasm for teamwork. These findings have important implications for classroom pedagogy and student career development.
\end{abstract}

Keywords: peer feedback, teams, teamwork, team assessment, team performance

\section{Introduction}

A movement toward small-group and team-based pedagogical methods has been taking place, prompted not only by research on how students can learn more effectively, but also by workplace trends. As educators, we seek to identify ways to communicate key course material, engage students, and support their learning, as well as to consider long-term issues, such as how to best prepare students for their futures. It is not surprising, then, that scholars have called for a shift from coursework designed for individual students to more collaborative learning environments. Indeed, the traditional methods where classroom learning is "a spectator sport in which faculty talk dominates" and that subjects students to "isolated" and "disconnected" learning (Tinto, 2003, p. 1) are being replaced by learning communities, cooperative or collaborative learning, and team-based pedagogies (Davidson, Major, \& Michaelsen, 2014). As these small-group learning approaches gain traction, educators look to practitioners, scholars, and published research on how to best use teams to maximize benefits to their students.

Extant research has provided guidance on how to form student teams, design assignments, and support the students in their group work (e.g., Cooper \& Robinson, 2011; Michaelsen, Knight, \& Fink, 2004; Millis, 2010). One area that has received less attention is how the type of peer feedback that team members receive impacts team outcomes. In this study, we compared the impact of general/non-benchmarked peer feedback ("conventional") to behaviorally-specific/benchmarked peer feedback ("enhanced") on team performance. The goal of the current research was to explore these two teammate evaluation methods and to examine how enhanced teammate evaluations can impact not only student team processes, but also student readiness and enthusiasm for working on future teams.

Before comparing team feedback modes, we first provide background on the movement toward teams both in industry and in the classroom. We also provide a review of the literature on peer evaluations - their applications, methods, and flaws - in team settings.

\subsection{Trends Toward Teaming in the Workplace}

According to the National Association for Colleges and Employers' 2016 Job Outlook survey, the ability to work 
on a team is one skill that employers are looking for in today's college graduates (NACE, 2015). Kagan provides a useful metaphor for this workplace trend: "Unlike the farmer who could work successfully alone, today the successful worker is a team member" (2011, p. 20). An earlier observation of teamwork's prevalence noted that teamwork happens "in the symphony, in the ballet, in the theater, in sports and equally in business" (Bradley, 1999, p. 292). Since then, the "teaming" trend (Edmondson, 2012) has become a widely accepted method of organizing work as we see employees working in offices with physical space designed for collaboration (Cain, 2012). This makes sense since today's work involves sharing knowledge, solving problems, and often taking action by working together whether in for-profit, not-for-profit, public, or private organizations (Ashmos \& Nathan, 2002; DeChurch \& Mesmer-Magnus, 2010; London, 2013; Riebe, Reopen, Santarelli, \& Marchioro, 2010).

However, trends and hiring preferences are not the only reasons for teaming in the workplace. Management and workplace psychology literatures have provided richly detailed, well-documented research demonstrating the benefits of using teams and small groups. The performance, productivity, and efficiency improvements of teaming have been illustrated, as have the potential for cost savings, improved problem solving, and more positive employee attitudes (Aubé, Rousseau, \& Tremblay, 2011; Beersma, Hollenbeck, Humphrey, Moon, Conlon, \& Ilgen, 2003; Campion, Medsker, \& Higgs, 1993; Dunphy \& Bryant, 1996; Hansen, 2006; Napier \& Gershenfeld, 2004; Richter, Dawson, \& West, 2011). For example, a recent meta-analysis demonstrated when healthcare workers learn team skills and team abilities (i.e., team training), key organizational outcomes result such as higher safety levels, more satisfied patients, and lower mortality rates (Hughes et al., 2016). Another meta-analysis of teams in military, business, aviation, medicine, labs, and universities found that $12-19 \%$ of performance outcomes are due to engaging in more effective team behaviors; for instance, communicating and making decisions as a team were linked to higher productivity levels (i.e., quantity; Salas et al., 2008).

The use of teams in the workplace is not a trend likely to pass by soon; the research evidence demonstrates teaming is "an effective means for organizations to enhance productivity", so we should not "view teamwork as a 'management fashion' to disappear in the course of time" (Richter et al., 2011, p. 2761). Thus, given the "direct impact" research can have on policies and practices "in the public and private sectors", there is still more to learn about how to make teams more effective, including the role of feedback (Kozlowski \& Ilgen, 2006, p. 111).

\subsection{The Use of Teams in Education}

The widespread use of teams in the workplace, noted above, is one key reason why we see the teaming trend in academia. In order to prepare students for the work world that awaits them, there is increasing evidence that "responsible pedagogy" (Cockburn-Wootten, Holmes, \& Simpson, 2008, p. 420) occurs when students can develop requisite critical analysis competencies, communication skills, habits for personal accountability, and skills for operating in a team setting (Aggarwal \& O’Brien, 2008; Capelli \& Rogovsky, 1994; Chen, Donahue, \& Klimoski, 2004; Hernandez, 2002; Hunsaker, Pavett, \& Hunsaker, 2011; Pfaff \& Huddleston, 2003; Quintessential Careers, 2004). Putting students in teams for small group work has been called one of the "most-often-used approaches to get students engaged in the classroom" (Davidson et al., 2014, p. 1) leading to articles on the topic in a variety of higher education journals (e.g., Journal on Excellence in College Teaching, Academy of Educational Leadership Journal, New Directions for Teaching and Learning) as well as books devoted to best practices for utilizing team pedagogies (e.g., Millis, 2010; Cooper \& Robinson, 2011). Some of the most talked about issues related to using student teams are forming teams, team size, role assignments, and designing effective team assignments (Michaelsen, Davidson, \& Major, 2014; Michaelsen et al., 2004). While feedback and assessment are also topics of concern (e.g., Angelo, 2011; Fink, 2004), there's still a great deal to learn about student teams and peer feedback.

\subsection{Peer Feedback}

Kozlowski and Ilgen call team feedback a "key leverage point and a pressing research need" (2006, p. 112). Citing over 50 years of research, their review of the literature demonstrates that, while there is a lot that we know about how to improve team effectiveness, the body of scholarship on "feedback... at the team level is not nearly so well developed" (2006, p. 112). This has implications not only for performance of student teams, but also for student learning and development as well as their future careers. As Michaelsen et al. note, peer assessments can help students "develop the interpersonal and teamwork skills that are so important for their future success" (2014, p. 68); moreover, researchers have demonstrated the centrality of peers to engagement in learning, GPA, and career perceptions (Grier-Reed, Appleton, Rodriguez, Ganuza, \& Reschly, 2012). For these reasons, we focused the current research on peer evaluations - in particular, on how two approaches to peer feedback on teamwork behaviors affects students' perceptions of team processes and their future teamwork preparedness.

Team feedback can be seen in a variety of applications. Peer evaluations/assessment, group performance feedback, 
and 360-degree feedback are all terms used to describe the collection of performance-related data from teammates, other students, or individuals on the same lateral hierarchical/educational level (Anson \& Goodman, 2014; Dominick, Reilly, \& McGourty, 1997; El-Mowafy, 2014; Pellecchia et al., 2011; Penny, 2003). The practice of using team feedback builds on the fact that "learning is an inherently social process" (El-Mowafy, 2014, p. 225; Gabelica, Van den Bossche, De Maeyer, Segers, \& Gijselaers, 2014) and that "team members can play an important role in enhancing and sustaining team effectiveness by providing feedback to each other" (Dominick et al., 1997, p. 509). Given the frustration students have expressed with unfair or dissatisfactory team assignments in classes, the use of peer assessment has been noted for its support of student learning and reduction of free riding (Anson \& Goodman, 2014); in sum, feedback is one of the most effective means for enhancing performance and learning in team settings (DeShon, Kozlowski, Schmidt, Milner, \& Wiechmann, 2004).

Student team assessments can also lead to enhanced content learning/retention, less social loafing (if students perceive that they'll have the opportunity to weigh in on whether their teammates made equal contributions to the group's work), better student experiences, improved team behavior and/or performance; improved team processes (i.e., becoming more self-managed rather than instructor-facilitated; developing team skills), and a more collective versus individual team orientation (e.g., collaboration, cohesion; Anson \& Goodman, 2014; Brutus \& Donia, 2010; El-Mowafy, 2014; Gabelica, Van den Bossche, Segers, \& Gijselaers, 2012; Loughry, Ohland, \& Moore, 2007; Michaelsen et al., 2014; Pellecchia et al., 2011; Van der Vegt, de Jong, Bunderson, \& Molleman, 2010). Clearly, the benefits of peer feedback are broad and far reaching. Getting feedback from peers makes sense, too, since students have access to performance data on their teammates that the faculty member is not privy to (Brutus \& Donia, 2010; Fink, 2004; Greguras, Robie, \& Born, 2001; Loughry et al., 2007; Michaelsen, 2004; Michaelsen et al., 2014; Ohland et al., 2012). Finally, in a way, using peer evaluations can result in more accurate assessments since the peer is an insider to the team and on the same level as the person being evaluated (Burton, 2005; Ohland et al., 2012).

\subsection{Potential Problems with Peer Feedback}

Despite its advantages, teammate peer evaluations can suffer from a variety of drawbacks. The feedback can be general rather than specific, lack a benchmark for performance, be biased, and be evaluative rather than formative. Each of these drawbacks is discussed below.

\subsubsection{General Feedback}

The methods and forms used to gather peer feedback can be too general and unspecific. For example, some experts on student team-based pedagogies recommend a simple evaluation survey at the end of the semester to assess each teammates' feelings about how the team performed, how helpful the teammates were to each other, and how their peers contributed to their learning (e.g., Michaelsen \& Fink, 2004; Opatrny, McCord, \& Michaelsen, 2014) or a time log method where students keep track of the time they put into their teamwork and ratings of their work quality each week (Angelo, 2011). Yet, when assessment calls for simple scale measures (e.g., rate your teammate on a scale of 1 to 5), students often respond with ratings that lack depth. Even the request for reasons or explanations can be ignored leading to feedback that essentially says they "weren't a good teammate".

In sum, without specific feedback, students lack guidance on what areas they need to develop as a team member. If the feedback were to identify specific behaviors where they are lacking, students could then focus on those areas and track improvement in subsequent evaluations.

\subsubsection{Lack of Benchmark}

Most common types of team member assessments described by Baker (2018) - such as rating scales, allocation of points, and project diaries - do not include benchmark information for students. With these methods, team members know how they are rated on certain behaviors using a scale, how many points were assigned to them for their overall team performance, or how many times during the project they demonstrated specific behaviors. Yet none of these assessment approaches gives students an idea of how their performance on specific behaviors compared to others in their team or class. The peer comparison method of providing feedback shows team members where they are ranked on performance dimensions related to their other team members, but that is the only feedback they receive on their behaviors. Providing students with information on where they stand on each item in an assessment as compared to other students in their teams or classes could spark motivation for improvement.

\subsubsection{Bias}

Students occupy several roles - they can be work colleagues on the same team but also close friends or roommates outside of class. This can lead to competing priorities when evaluating each other where peers can put the 
maintenance of their relationship (i.e., friendship) or a desire to take revenge on their teammates above honesty in their assessments, resulting in inaccurate ratings (Burton, 2005; Loughry et al., 2007; Ohland et al., 2012). In addition, distributive justice can contribute to biased team assessments. High performers have been shown to provide more variable and distinguishing peer ratings while low performers on the team distinguish less between good and bad teammates (Davison, Mishra, Bing, \& Frink, 2014; Ohland et al., 2012). Ohland et al. (2012) contend this can have implications for accurate, fair, and useful peer assessments in team settings. Students can choose to ignore or challenge the validity of team feedback they perceive as biased (Eddy, D'Abate, \& Costello, 2019).

\subsubsection{Evaluative Feedback}

Peer feedback can be more evaluative than developmental. For example, when teammate feedback is given only at the end of the project (e.g., Fink, 2004), the assessment often factors into each student's grade - missing an opportunity for development when students can consider the feedback and change their behavior while still working on the team. This can happen when too much emphasis is placed on the team's output (e.g., a presentation, a paper, a business plan) instead of the process the team engaged in (Kozlowski \& Ilgen, 2006). Instead, authors tend to agree that peer feedback should be frequent, immediate, and tied to accountability to the student team (Michaelsen et al., 2014) if students are not only to learn the material but to also develop requisite teamwork skills (Kozlowski \& Ilgen, 2006). Anson and Goodman (2014) call this "formative" assessment to support team processes rather than "summative" feedback after the team's work is completed (2014, p. 27).

\section{Hypotheses}

Despite all that is known about teamwork and peer feedback, "how much students learn from the process of providing feedback to peers" is less understood (Patchan \& Schunn, 2015, p. 592). Thus, the type of feedback that students who work in learning teams receive - particularly peer feedback about team processes and dynamics that are behaviorally specific and benchmarked to peers - was our focus. Our research explored two methods for evaluating students working in teams that we labeled "conventional" and "enhanced" and examined how those two approaches can impact team processes and individual outcomes including students' perceived readiness and enthusiasm for working on future teams.

Team process outcomes were selected as important because they relate to student perceptions of how well their team worked together on the projects. Receiving peer feedback would hopefully prompt individual team members to make behavioral adjustments that would lead to a perceived improvement in the team's dynamics. Team process outcomes include student perceptions of the degree to which their team prioritized and agreed on goals and tasks (transition processes), managed their time (action processes), and managed the exchange of ideas (interpersonal processes) (Mathieu \& Marks, 2006). In addition to knowing student perceptions of how well their teams worked together, it is also important to look at how ready they feel and how enthusiastic they are to work in future teams (for career development purposes) (Eddy, Tannenbaum \& Mathieu, 2013). Our goal as instructors is to prepare students to contribute to teams, and, given the pervasiveness of teams throughout organizations, hopefully have them leave the teams in our classes feeling confident in their ability to function in future teams and enthusiastic for their next team experience.

Hence, we identified the following hypotheses:

H1: Enhanced teammate evaluations will improve team processes more than conventional teammate evaluations.

$\mathrm{H} 2$ : Enhanced teammate evaluations will improve team member enthusiasm for teaming more than conventional teammate evaluations.

H3: Enhanced teammate evaluations will improve team member readiness for teamwork more than conventional teammate evaluations.

\section{Methods}

\subsection{Participants}

Data were collected from 52 senior level business students enrolled in two class sections of a Strategic Management course in a small northeastern university. Within each class, students were randomly assigned to five teams, although an attempt was made to have an equal representation of majors while composing the teams (i.e., marketing, management, finance, accounting, economics). Overall, there were eight five-member teams and two six-member teams. On average, participants were 21.2 years old, $92 \%$ Caucasian, and $49 \%$ were women. The representations of majors were: $25 \%$ accounting, $18 \%$ finance, $33 \%$ marketing, $22 \%$ management, and $2 \%$ economics. This was one group project among many experienced by these participants (students reported engaging 
in an average of 4.12 group projects per year $(\mathrm{SD}=2.73)$.

Typically, the teams examined in the current study would be referred to as "project teams" or "student teams" (Sundstrom, 1999). However, as Tannenbaum, Mathieu, Salas, \& Cohen (2012) suggest, teams are changing, and our description of teams must be more precise. Hollenbeck, Beersma, \& Schouten (2012) provide a dimensional scaling conceptualization for describing teams. Similar to past research (Eddy, Tannenbaum, \& Mathieu, 2013), using the Hollenbeck et al. (2012) dimensions of skill differentiation, authority differentiation, and temporal stability, we would describe the current teams as: high in skill differentiation - teammates were not easily interchangeable and students on teams represented various functions (i.e., management, marketing, finance, accounting, and economics); low in authority differentiation - no one person held a position of formal authority or leadership on the team; and moderate in temporal stability - as a student project team, teammates only worked together for fifteen weeks.

\subsection{Procedures}

During the semester, teams read four case studies (e.g., Harvard Business School cases) on four separate organizations. Teams reviewed the company facts, analyzed the current situation, and developed a five-year recommended strategic plan for each company. The student teams completed these four business case analyses over the 10-week semester. Each team also did an oral presentation on one of the cases; team presentations were distributed through the semester. After each case, students engaged in teammate evaluations (either "conventional" or "enhanced") to provide feedback on team member performance. The differences between the conventional and enhanced feedback conditions are summarized below.

In the "conventional" condition, students completed a one-page teammate evaluation after each case project that described the characteristics of poor, good, and great behaviors related to four categories - do the work, show up, contribute, and cooperate (see Appendix A). For each category, students were asked to provide a score (on a scale of $0 \%$ to $100 \%$ ) for each team member. The instructor then averaged the scores in each of the four categories that were assigned to them by their teammates and provided students with those averages in the next class session.

In the second condition, students completed an "enhanced" teammate evaluation using an online assessment tool named TEAMS 101, which was developed by one of the authors. This evaluation was also administered following the completion of each case, but the feedback students received from the enhanced evaluation differed from what students received in the conventional condition in two ways. One, students received a comprehensive analysis of their performance on multiple team behaviors and, two, students were provided with a comparison of how their team member ratings were related to those of the other members of their class. Feedback was anonymous.

Using the enhanced team member evaluation, each student was evaluated on 48 unique team member behaviors within each of the same four categories included in the evaluation used in the first condition (i.e., doing the work, showing up for meetings, contributing to group discussions, and cooperating with team members). For instance, some of the specific behaviors students were asked to provide peer ratings for in the "do the work" category included the following: is not prepared, doesn't do the work, work is of poor quality, minimal contributions, defines task, understands goals, and organizes work of others (see Appendix B).

The enhanced approach allowed the feedback to be analyzed on multiple behavioral dimensions multiple times throughout the semester, and the summary and comparative information was provided to each student. Hence, the enhanced individualized assessment report provided behaviorally specific feedback on ways students could improve their performance as team members moving forward. In addition to receiving feedback related to 48 specific team performance behaviors, the report also identified how each student's performance compared to other members of the class.

\subsection{Measures}

At the end of the semester, following the fourth case, students in both conditions completed a survey that assessed their perception of their team processes, their individual readiness for teamwork, and their enthusiasm for teaming. All items were answered using five-point Likert-type response scales that ranged from " 1 " (Not at all) to "5" (To a very great extent).

\subsubsection{Team Processes}

Team processes were measured using multi-item scales developed by Mathieu and Marks (2006), which correspond to Marks, Mathieu, \& Zaccaro's (2001) three super-ordinate categories. The three scales each exhibited acceptable psychometric properties and were highly correlated, so we averaged them to form a composite team process score (Eddy, Tannenbaum, \& Mathieu, 2013). LePine, Piccolo, Jackson, Mathieu, \& Saul (2008) found 
support for a single, higher-order process dimension underlying the three separate subscales, thereby justifying this approach.

\subsubsection{Readiness for Teamwork}

A 9-item scale was utilized to assess individual perceptions of level of readiness for working in future teams based on their experience with the team in their current class (Eddy et al., 2012). Items included, "I feel better prepared to lead teams in the future as a result of my experiences with this team", "Being a part of this team will help me be a more effective member of teams in the future", and "I learned about teamwork by participating in this team".

\subsubsection{Enthusiasm for Teaming}

A 9-item scale was utilized to assess individual perceptions of enthusiasm for teaming (Eddy et al., 2012). Items included, "Being on this team has decreased my enthusiasm for working in team settings in the future", "Given my experience with this team, I would prefer to work alone in the future", and "If I could have left this team, I would have done so."

\section{Results}

Analysis of Variance (ANOVA) was utilized to assess the three hypotheses. Hypothesis one stated that enhanced teammate evaluations would improve student perceptions of their team processes more than conventional teammate evaluations. Results shown in Table 1 provide support for this hypothesis $(\mathrm{F}=10.185, \mathrm{p}<.002)$ with mean differences shown in Table 2 of 4.16 for the enhanced evaluation and 3.77 for the conventional evaluation.

Table 1. ANOVA results

\begin{tabular}{|c|c|c|c|c|c|c|}
\hline & & Sum of Squares & df & Mean Square & $\mathbf{F}$ & Sig. \\
\hline & Between Groups & 1.867 & 1 & 1.867 & 10.185 & .002 \\
\hline \multirow[t]{3}{*}{ Team Processes } & Within Groups & 9.167 & 50 & .183 & & \\
\hline & Total & 11.035 & 51 & & & \\
\hline & Between Groups & 1.849 & 1 & 1.849 & 3.106 & .049 \\
\hline \multirow[t]{3}{*}{ Enthusiasm for Teaming } & Within Groups & 30.359 & 51 & .595 & & \\
\hline & Total & 32.208 & 52 & & & \\
\hline & Between Groups & 1.006 & 1 & 1.006 & 1.518 & .224 \\
\hline \multirow[t]{2}{*}{ Readiness for Teaming } & Within Groups & 33.799 & 51 & .663 & & \\
\hline & Total & 34.805 & 52 & & & \\
\hline
\end{tabular}

Hypothesis two stated that enhanced teammate evaluations would improve increased team member enthusiasm for teaming more than conventional teammate evaluations. Results shown in Table 1 provide support for this hypothesis $(\mathrm{F}=3.10, \mathrm{p}<.049)$ with mean differences shown in Table 2 of 4.12 for enhanced evaluations and 3.75 for conventional evaluations.

Hypothesis three stated that enhanced teammate evaluations would improve students' perceived readiness for future teamwork more than conventional teammate evaluations. While the mean differences were in the correct direction (4.27 for enhanced evaluations and 4.00 for conventional evaluations), statistically significant differences were not found $(\mathrm{F}=1.51, \mathrm{p}=.224)$. 
Table 2. Mean differences

\begin{tabular}{lcc}
\hline & Condition & Mean \\
\hline Team Processes & Enhanced & 4.16 \\
& Conventional & 3.77 \\
\hline \multirow{2}{*}{ Enthusiasm for Teaming } & Enhanced & 4.12 \\
\hline \multirow{2}{*}{ Readiness for Teaming } & Conventional & 3.75 \\
\hline
\end{tabular}

\section{Discussion}

Surveys "consistently show that students are less satisfied with feedback than with any other feature of their courses" (Nicol, Thomson, \& Breslin, 2014, p. 102), and DeShon et al. states that the "effects of feedback on team processes and performance are not nearly as well understood" (2004, p. 1036). This study has the potential to improve our understanding of how the characteristics of teammate evaluations impact student perceptions of individual and team outcomes. These insights can be used to improve student satisfaction with, and learning from, peer feedback.

The current research focused on developing and testing conventional versus enhanced versions of teammate evaluations and their impact on team processes (i.e., action processes, transition processes, and interpersonal processes) and individual processes (i.e., readiness and enthusiasm for teaming). The conventional teammate evaluations used in this study were formative (given after each team project during the semester), included feedback on limited general performance categories, and did not provide students with an understanding of how their performance in the team compared to that of their teammates. The enhanced evaluations used in this study were also administered multiple times throughout the semester, but they provided students with feedback on specific team behaviors and gave students an idea of how they compared to their peers on each behavior.

The findings of the current research suggest that teammate evaluations with enhanced features had substantial benefits over the conventional evaluations for the students and their teams. Enhanced evaluations related to more positive perceptions of team processes. This is exceptionally important for students who are learning how to be effective team members. The students who received more specific and benchmarked feedback about their behaviors in their teams reported more positive ratings of their team processes including the team's ability to set goals, manage time, and share ideas. If our goal as instructors is to improve students' team skills, enhanced evaluations appear to facilitate the perception of that kind of growth, which leads to a perceived improvement in teams' abilities to successfully work together.

This study also shows that enhanced evaluations are positively related to students' enhanced enthusiasm for teamwork. Given the reliance on teams in all aspects of the work world, having students leave our institutions with positive attitudes toward working with future teams will be beneficial to them in their job search and in their participation with their workplace teams. We know it is not uncommon to find diverse teams of employees solving complex problems at firms such as Coca-Cola, Nokia, and Ford; in hospital operating rooms or research labs, museums, and engineering quality teams; or addressing crime, environmental disasters, or political strategy (American Society for Quality, 2014; Ashmos \& Nathan, 2002; Buljac-Samardzic, Dekker-van Doorn, van Wijngaarden, \& van Wijk, 2010; DeChurch \& Mesmer-Magnus, 2010; Decuyper, Dochy, \& Van den Bossche, 2010; DeDreu \& Weingart, 2003; Jordan et al., 2002; London, 2013; London \& Sessa, 2006; Mankins, Bird, \& Root, 2013; Mesmer-Magnus \& DeChurch, 2009; Museum of Modern Art, 2011; Peeters, Van Tiujl, Rutte, \& Reymen, 2006; Prokesch, 2009; Tata \& Prasad, 2004; Werner \& Lester, 2001; Zaccaro, Ely, \& Shuffler, 2008). Therefore, a student's enthusiasm for working with future teams is an important factor influencing success in a team-based organizational structure.

Additional research could add to what we learned in this study about conventional and enhanced team member evaluations. This study addressed two potential problems with team member evaluations - general feedback and the lack of benchmarks. The potential bias that may appear in student peer feedback was not directly addressed in this study. A future study could look at how the conventional and enhanced approaches relate to bias in team member evaluations. When students are asked to rate team members on specific identifiable behaviors related to each performance category, their feedback might be less biased than when rating a teammate on broad general 
categories. For instance, when a student is evaluating a teammate on the degree to which they generally "contributed to the team", the evaluator may be hesitant to rate a poor-performing peer low in this broad area. But, when asked to rate a teammate on specific "contribute" behaviors, such as "took the group off track" or "does not participate", the measurement options may provide more nuanced responses regarding their team member's contribution. In addition, research has shown that a five-minute class training session can reduce bias in team member evaluations so students focus more on performance than non-performance factors in their ratings (Eddy, D'Abate, \& Costello, 2019). If the enhanced evaluations do not positively relate to a reduced evidence of bias in student team member evaluations, training for peer feedback is another strategy instructors can use to mitigate the impact of bias.

There are limitations to the current study that should be noted. First, although our sample included 52 students, $92 \%$ were Caucasian. It would be valuable to know if a more diverse group of students would demonstrate the same perceptions. Also, all of the students in our sample were business students. There is the possibility that students from other majors outside a business discipline would react differently to conventional or enhanced team evaluations.

Finally, the difference in the delivery method for the conventional evaluations as compared to the enhanced evaluations should be considered. The conventional evaluation consisted of a form students printed, filled out, and submitted as a hard copy to the instructor. The instructor summarized the data for each student and distributed individual feedback in the following class. The enhanced evaluations were completed online and students received their individual reports as soon as all students in the team completed the evaluations. While we doubt that these minor variations in the delivery approach of the two evaluations would explain the results, it is worth noting the difference.

As for practical implications of this study, enhanced evaluations provided extensive and detailed feedback to each student without a significant impact on the amount of time the instructor commits to class. Beyond approximately five minutes to enter student information into TEAMS 101, the application functioned with limited support for the remainder of the semester. Unfortunately, instructors can't easily incorporate behaviorally specific and benchmarked feedback into their classes without the support of an online application. Processing student feedback on 48 behavioral dimensions with benchmark information without the benefit of an online application would be unreasonable for an instructor.

Even incorporating a conventional peer feedback approach at the end of the semester - with students ranking their team members' general performance on a limited number of behaviors - creates an increased workload on the faculty member (e.g., moderating the assessments to avoid leniency, entering all of the peer ratings, and providing summaries to team members; Anson \& Goodman, 2014; Bouzidi \& Jaillet, 2009; El-Mowafy, 2014). Incorporating peer teammate evaluations following team projects throughout the semester provides formative assessment, but the burden for the instructor is multiplied. Moreover, due to the administrative time required to conduct teammate evaluations either at multiple points throughout the semester or at the end of the semester, instructors might understandably request peer team member assessment based on a few general categories of team performance. However, since "enhanced" teammate evaluations that provided feedback on a number of specific team behaviors and benchmarks for performance were shown to be related to important individual and team outcomes, instructors may be willing to incorporate them in their classes, despite the workload.

Furthermore, moving online for peer assessment provides time savings for administrators and may lead to less social desirability effects, less missing data, and fewer human errors that can come from instructors having to enter/process the rating data (Fouladi, McCarthy, \& Moller, 2002). As shown here, an online peer assessment system can also allow for more informative feedback for students. However, an online program for team member evaluations requires an upfront investment of time or money. TEAMS 101 was developed by one of the authors as a senior project with a student computer science major. Alternatives to TEAMS 101 may be developed by individual instructors (see Freeman \& McKenzie, 2002) or through partnering with paid online performance evaluation services as a way to make the team member feedback process in their classes more streamlined and informative. Other platforms such as Excel and Qualtrics may also be utilized to make the feedback process more efficient.

\section{Conclusion}

Researchers are keen to point out how prevalent teamwork is in organizations. A recent culturomics analysis (akin to content analysis) found that teamwork has "gained momentum" in terms of its societal diffusion (Weiss \& Hoegl, 2015, p. 599); the same researchers' bibliometric analysis added that scholarship on the topic has also seen "steady and rapidly increasing prevalence of teamwork in the past three decades" (p. 606). Since the New York Times tells 
its readers, "Solitude is out of fashion.....Most of us now work in teams, in offices without walls, for managers who prize people skills above all. Lone geniuses are out. Collaboration is in" (Cain, 2012), it makes sense, then, that organizations across industries are expecting employees to have an appreciation for team factors and team cultures. We see this theme repeat itself in major historical events; for example, the lack of a team culture was identified as a source of NASA's 2003 Columbia explosion and the failure to share information across teams was "a key factor" in the 9/11 terrorist attacks (Marks, 2006, p. i).

To optimize teams, though, peer feedback has been called essential to team experiences and behavioral improvements. It can improve learning and performance in team settings and the effects can be powerful (Gabelica et al., 2014). According to Anson and Goodman, "Without feedback, students will not be able to learn to improve their behaviors - this time, or the next time around" (2014, p. 33). What's interesting, too, is that it is not just a matter of getting the feedback that makes a difference. As Dominick et al. (1997) found, simply being exposed to and completing peer feedback instruments can lead to behavioral improvements. So, the pedagogical benefits of peer evaluation are twofold: students benefit from providing it and from receiving it (van der Pol et al., 2008).

Taken together, the goals of higher education are far from simple. Deep learning, promoting intellectual curiosity, intellectual and personal development, and benefits to society are some of the objectives of college and university education (Chan, 2016; Keniston, 1960; Sandoval-Lucero, 2014). Preparing students for their careers is another goal (Association of American Colleges and Universities [AAC\&U], 2013; Chan, 2016; Keniston, 1960; Sandoval-Lucero, 2014; White House, n.d.), Engaging in peer feedback in classroom settings is good training for "an important and difficult organizational duty" that they'll be required to perform in their professional careers (Brutus \& Donia, 2010, p. 652; Ohland et al., 2012; van der Pol, van den Berg, Admiraal, \& Simons, 2008). With that, findings from the current study tell us team member evaluations that give students specific feedback on a range of team behaviors and that benchmark their performance to that of their team members relate to students' positive perceptions of their team processes and their enthusiasm to work in future teams. Educators can use these findings wherever they apply team learning. Keeping the teammate evaluations specific and comparative and providing the feedback to students at a time (or times) when development can still occur within the team setting are simple steps to help students appreciate the complex processes (i.e., transition, action, interpersonal) that occur in teams and build enthusiasm for future team work - all while giving them training in the complexities and importance of peer evaluations.

\section{References}

Aggarwal, P., \& O'Brien, C. L. (2008). Social loafing on group projects: Structural antecedents and effect on student satisfaction. Journal of Marketing Education, 30(3), 255-264. https://doi.org/10.1177/0273475308322283

American Society for Quality. (2014). 2014 International Team Excellence Awards. Retrieved January 9, 2017, $\mathrm{http}$ ://wcqi.asq.org/team-award/case-studies.html

Angelo, T. A. (2011). Using assessment to improve cooperative learning. In J. L. Cooper \& P. Robinson (Eds.), Small group learning in higher education: Research and Practice (pp. 47-49). Stillwater, OK: New Forums Press.

Anson, R., \& Goodman, J. A. (2014). A peer assessment system to improve student team experiences. Journal of Education for Business, 89, 27-34. https://doi.org/10.1080/08832323.2012.754735

Ashmos, D. P., \& Nathan, M. L. (2002). Team sense-making: A mental model for navigating uncharted territories. Journal of Managerial Issues, 14(2), 198-217.

Association of American Colleges and Universities [AAC\&U]. (2013, October). Why are students going to college and what are they studying? Data from the 2013 Chronicle of Higher Education Almanac. Retrieved June 18, 2014, from http://www.aacu.org/aacu_news/aacunews13/october13/facts_figures.cfm

Aubé, C., Rousseau, V., \& Tremblay, S. (2011). Team size and quality of group experience: The more the merrier. Group Dynamics: Theory, Research and Practice, 15(4), 357-75. https://doi.org/10.1037/a0025400

Baker, D. F. (2008). Peer assessment in small groups: A comparison of methods. Journal of Management Education, 33, 183-209. https://doi.org/10.1177/1052562907310489

Beersma, B., Hollenbeck, J., Humphrey, S., Moon, H., Conlon, D., \& Ilgen, D. (2003). Cooperation, competition, and team performance: Toward a contingency approach. Academy of Management Journal, 46, 572-590. https://doi.org/10.2307/30040650

Bouzidi, L., \& Jaillet, A. (2009). Can online peer assessment be trusted? Educational Technology \& Society, 12(4), 
257-268.

Bradley, R. T. (1999). Charisma and social structure. New York: toExcel.

Brutus, S., \& Donia, M. L. (2010). Improving the effectiveness of students in groups with a centralized peer evaluation system. Academy of Management Learning \& Education, 9(4), 652-662. https://doi.org/10.5465/AMLE.2010.56659882

Buljac-Samardzic, M., Dekker-van Doorn, C. M., van Wijngaarden, J. D. H., \& van Wijk, K. P. (2010). Interventions to improve team effectiveness: A systematic review. Health Policy, 94, 183-195. https://doi.org/10.1016/j.healthpol.2009.09.015

Burton, K. S. (2005). Using student peer evaluations to evaluate team taught lessons. Journal of Instructional Psychology, 32(2), 136-138.

Cain, S. (2012, January 13). The rise of the new groupthink. The New York Times. Retrieved January 9, 2017, from http://www.nytimes.com/2012/01/15/opinion/sunday/the-rise-of-the-new-groupthink.html?pagewanted=all \&_r $=0$

Campion, M. A., Medsker, G. J., \& Higgs, A. (1993). Relations between work group characteristics and effectiveness: Implications for designing effective work groups. Personnel Psychology, 46(4), 823-850.

Capelli, P., \& Rogovsky, N. (1994). New work systems and skill requirements. International Labor Review, 133, 204-220.

Chan, R.Y. (2016). Understanding the purpose of higher education: An analysis of the economic and social benefits for completing a college degree. Journal of Education Policy, Planning and Administration, 6(5), $1-40$.

Chen, G., Donahue, L. M., \& Klimoski, R. J. (2004). Training undergraduates to work in organizational teams. Academy of Management Learning \& Education, 3(1), 27-40. https://doi.org/10.5465/amle.2004.12436817

Cockburn-Wootten, C., Holmes, P., \& Simpson, M. (2008). Teaching teamwork in business communication/management programs. Business Communication Quarterly, 71(4), 417-420.

Cooper, J. L., \& Robinson, P. (2011). Small group learning in higher education: Research and practice. Stillwater, OK: New Forums Press.

Davidson, N., Major, C. H., \& Michaelsen, L. K. (2014). Small-group learning in higher education - cooperative, collaborative, problem-based, and team-based learning: An introduction by the guest editors. Journal on Excellence in College Teaching, 25(3-4), 1-6.

Davison, H. K., Mishra, V., Bing, M. N., \& Frink, D. D. (2014). How individual performance affects variability of peer evaluations in classroom teams: A distributive justice perspective. Journal of Management Education, 38(1), 43-85. https://doi-org/10.1177/1052562912475286

De Dreu, C. K. W., \& Weingart, L. R. (2003). Task versus relationship conflict, team performance, and team member satisfaction: A meta-analysis. Journal of Applied Psychology, 88(4), 741-749. https://doi.org/10.1037/0021-9010.88.4.741

DeChurch, L. A., \& Mesmer-Magnus, J. R. (2010). Measuring shared team mental models: A meta-analysis. Group Dynamics: Theory, Research, and Practice, 14(1), 1-14. https://doi.org/10.1037/a0017455

DeCuyper, S., Dochy, F., \& Van den Bossche, P. (2010). Grasping the dynamic complexity of team learning: An integrative model for effective team learning in organisations. Educational Research Review, 5(2), 11-133.

DeShon, R. P., Kozlowski, S. W. J., Schmidt, A. M., Milner, K. R., \& Wiechmann, D. (2004). A multiple-goal, multilevel model of feedback effects on regulation of individual and team performance. Journal of Applied Psychology, 89(6), 1035-1056. https://doi.org/10.1037/0021-9010.89.6.1035

Dominick, P. G., Reilly, R. R., \& McGourty, J. W. (1997). The effects of peer feedback on team member behavior. Group \& Organization Management, 22(4), 508-520. https://doi.org/10.1177/1059601197224006

Dunphy, D., \& Bryant, B. (1996). Teams: Panaceas or prescriptions for improved performance? Human Relations, 49(5), 677-699. https://doi.org/10.1177/001872679604900507

Eddy, E. R., D’Abate, C. D., \& Costello, M. (February 2019). What are students thinking? Examining the usefulness of teammate evaluations. Paper presented at the annual Lilly Conference on Evidence-Based Teaching and Learning, Anaheim, CA. 
Eddy, E. R., Tannenbaum, S. T., \& Mathieu, J. (2013). Helping teams to help themselves: Comparing two self-guided debriefing methods. Personnel Psychology, 66(4), 975-1008. https://doi.org/10.1111/peps.12041

Edmondson, A. C. (2012, April 25). The importance of teaming. Harvard Business School Working Knowledge. Retrieved January 9, 2017, from http://hbswk.hbs.edu/item/6997.html

El-Mowafy, A. (2014). Using peer assessment of fieldwork to enhance students' practical training. Assessment \& Evaluation in Higher Education, 39(2), 223-241. https://doi.org/10.1080/02602938.2013.820823

Fink, L. D. (2004). Beyond small groups: Harnessing the extraordinary power of learning teams. In L. K. Michaelsen, A. B. Knight, \& A. D. Fink (Eds.), Team-based learning: A transformative use of small groups in college teaching. Sterling, VA: Stylus Publishing.

Fouladi, R. T., McCarthy, C. J., \& Moller, N. P. (2002). Paper-and-pencil or online? Evaluating mode effects on measures of emotional functioning and attachment. Assessment, 9(2), 204-215. https://doi.org/10.1177/10791102009002011

Freeman, M., \& McKenzie, J. (2002). SPARK, a confidential web-based template for self and peer assessment of student teamwork: Benefits of evaluating across different subjects. British Journal of Educational Technology, 33(5), 551-569. https://doi.org/10.1111/1467-8535.00291

Gabelica, C., Van den Bossche, P., De Maeyer, S., Segers, M., \& Gijselaers, W. (2014). The effect of team feedback and guided reflexivity on team performance change. Learning and Instruction, 34, 86-96. https://doi.org /10.1016/j.learninstruc.2014.09.001

Gabelica, C., Van den Bossche, P., Segers, M., \& Gijselaers, W. (2012). Feedback, a powerful level in teams: A review. Educational Research Review, 7(2), 123-144.

Greguras, G. J., Robie, C., \& Born, M. P. (2001). Applying the social relations model to self and peer evaluations. Journal of Management Development, 20(6), 508-525. https://doi.org /10.1108/02621710110399792

Grier-Reed, T., Appleton, J., Rodriguez, M., Ganuza, Z., \& Reschly, A. L. (2012). Exploring the student engagement instrument and career perceptions with college students. Journal of Educational and Developmental Psychology, 2(2), 85-96.

Hansen, R. S. (2006). Benefits and problems with student teams: Suggestions for improving team projects. Journal of Education for Business, 82(1), 11-19. https://doi.org /10.3200/JOEB.82.1.11-19

Hernandez, S. (2002). Team learning in a marketing principles course: Cooperative structures that facilitate active learning and higher level thinking. Journal of Marketing Education, 24(1), 73-85.

Hollenbeck, J. R., Beersma, B., \& Schouten, M. E. (2012). Beyond team types and taxonomies: A dimensional scaling conceptualization for team description. The Academy of Management Review, 37(1), 82-106.

Hughes, A. M., Gregory, M. E., Joseph, D. L., Sonesh, S. C., Marlow, S. L., Lacerenza, C. N., Benishek, L. E., King, H. B., \& Salas, E. (2016). Saving lives: A meta-analysis of team training in healthcare. Journal of Applied Psychology, 101(9), 1266-1304. https://doi.org/10.1037/apl0000120

Hunsaker, P., Pavett, C., \& Hunsaker, J. (2011). Increasing student-learning team effectiveness with team charters. Journal of Education for Business, 86(3), 127-139. https://doi.org /10.1080/08832323.2010.489588

Jordan, M. H., Field, H. S., \& Armenakis, A. A. (2002). The relationship of group process variables and team performance: A team-level analysis in a field setting. Small Group Research, 33(1), 121-150.

Kagan, S. (2011). An instructional revolution for higher education: Rationale and proposed methods. In J.L. Cooper \& P. Robinson (Eds.), Small group learning in higher education: Research and Practice (pp. 19-24). Stillwater, OK: New Forums Press.

Keniston, H. (1960). The goals of higher education. Proceedings of the American Philosophical Society, 104(6), 565-569.

Kozlowski, S. J., \& Ilgen, D. R. (2006). Enhancing the effectiveness of work groups and teams. Psychological Science in the Public Interest, 7(3), 77-124. https://doi.org/10.1111/j.1529-1006.2006.00030.x

LePine, J. A., Piccolo, R. F., Jackson, C. L., Mathieu, J. E., \& Saul, J. R. (2008). A meta-analysis of teamwork processes: Tests of a multidimensional model and relationships with team effectiveness criteria. Personnel Psychology, 61(2), 273-307. https://doi.org/10.1111/j.1744-6570.2008.00114.x

London, M. (2013). Generative team learning in Web 2.0 environments. Journal of Management Development, 
32(1), 73-95. https://doi.org/10.1108/02621711311287035

London, M., \& Sessa, V. I. (2006). Group feedback for continuous learning. Human Resource Development Review, 5(3), 303-329. https://doi.org/10.1177/1534484306290226

Loughry, M. L., Ohland, M. W., \& Moore, D. D. (2007). Development of a theory-based assessment of team member effectiveness. Educational and Psychological Measurement, 67(3), 505-524. https://doi.org $/ 10.1177 / 0013164406292085$

Mankins, M., A. Bird, \& J. Root. (2013). Making star teams out of star players. Harvard Business Review. January-February. $\quad$ Retrieved January $9, \quad 2017$, from http://hbr.org/2013/01/making-star-teams-out-of-star-players/ar/

Marks, M. (2006). The science of team effectiveness. Psychological Science in the Public Interest, 7(3), i. https://doi.org/10.1111/j.1529-1006.2006.00029.x

Marks, M. A., Mathieu, J. E., \& Zaccaro, S. J. (2001). A temporally based framework and taxonomy of team processes. Academy of Management Review, 26(3), 356-376.

Mathieu, J. E., \& Marks, M. A. (2006). Team process items. University of Connecticut.

Mesmer-Magnus, J. R., \& DeChurch, L. A. (2009). Information sharing and team performance: A meta-analysis. Journal of Applied Psychology, 94(2), 535-546. https://doi.org /10.1037/a0013773

Michaelsen, L. K. (2004). Getting started with team-based learning. In L. K. Michaelsen, A. B. Knight, and A. D. Fink (Eds.) Team-based learning: A transformative use of small groups in college teaching (pp. 27-50). Sterling, VA: Stylus Publishing.

Michaelsen, L. K., \& Fink, L. D. (2004). Calculating peer evaluation scores. In L. K. Michaelsen, A. B. Knight, \& A. D. Fink (Eds.), Team-based learning: A transformative use of small groups in college teaching (pp. 229-239). Sterling, VA: Stylus Publishing.

Michaelsen, L. K., Davidson, N., \& Major, C. H. (2014). Team-based learning practices and principles in comparison with cooperative learning and problem-based learning. Journal on Excellence in College Teaching, 25(3-4), 57-84.

Michaelsen, L. K., Knight, A. B., \& Fink, A. D. (2004). Team-based learning: A transformative use of small groups in college teaching. Sterling, VA: Stylus Publishing.

Millis, B. J. (2010). Cooperative learning in higher education: Across the disciplines, across the Academy. Sterling, VA: Stylus Publishing.

Museum of Modern Art. (2011). Inside/Out: Foreclosed: Teamwork. Retrieved January 9, 2017, from http://www.moma.org/explore/inside_out/2011/06/30/foreclosed-team-work/

Napier, R. W., \& Gerschenfeld, M. K. (2004). Groups: Theory and Experience. Boston, MA: Houghton Mifflin.

National Association of Colleges and Employers [NACE]. (2015, November 18). Job outlook 2016: Attributes employers want to see on new college graduates' resumes. Retrieved August 3, 2016, from $\mathrm{http}$ ://www.naceweb.org/s11182015/employers-look-for-in-new-hires.aspx

Nicol, D., Thomson, A., \& Breslin, C. (2014). Rethinking feedback practices in higher education: A peer review perspective. Assessment \& Evaluation in Higher Education, 39(1), 102-122.

Ohland, M. W., Loughry, M. L., Woehr, D. J., Bullard, L. G., Felder, R. M., Finelli, C. J., Layton, R. A., Pomeranz, H. R., \& Schmucker, D. G. (2012). The comprehensive assessment of team member effectiveness: Development of a behaviorally anchored rating scale for self- and peer evaluation. Academy of Management Learning \& Education, 11(4), 609-630. https://doi.org/10.5465/amle.2010.0177

Opatrny, C., McCord, M., \& Michaelsen, L. (2014). Can transferable team skills be taught? A longitudinal study. Academy of Educational Leadership Journal, 18(2), 61-72.

Patchan, M. M., \& Schunn, C. D. (2015). Understanding the benefits of providing peer feedback: How students respond to peers' texts of varying quality. Instructional Science, 43(5), 591-614. https://doi.org/10.1007/s11251-015-9353-x

Peeters, M. A. G., Van Tiujl, H. F. J. M., Rutte, C. G., \& Reymen, I. M. M. J. (2006). Personality and team performance: A meta-analysis. European Journal of Personality, 20, 377-396. https://doi.org/10.1002/per.588 
Pellecchia, M., Connell, J. E., Eisenhart, D., Kane, M., Schoener, C., Turkel, K., Riley, M., \& Mandell, D. S. (2011). We're all in this together now: Group performance feedback to increase classroom team data collection. Journal of School Psychology, 49, 411-431. https://doi.org/10.1016/j.jsp.2011.04.003

Penny, J. A. (2003). Exploring differential item functioning in a 360-degree assessment: Rater source and method of delivery. Organizational Research Methods, 6(1), 61-79. https://doi.org /10.1177/1094428102239426

Pfaff, E., \& Huddleston, P. (2003). Does it matter if I hate teamwork? What impacts student attitudes toward teamwork. Journal of Marketing Education, 25(1), 37-45.

Prokesch, S. (2009, January). How GE teaches teams to lead change. Harvard Business Review. Retrieved January 9, 2017, from http://hbr.org/2009/01/how-ge-teaches-teams-to-lead-change/ar/1

Quintessential Careers. (2004) Retrieved September 13, 2011, from http://www.quintcareers.com/

Richter, A. W., Dawson, J. F., \& West, M. A. (2011). The effectiveness of teams in organizations: A meta-analysis. The International Journal of Human Resource Management, 22(13), 2749-2769. https://doi.org/10.1080/09585192.2011.573971

Riebe, L., Roepen, D., Santarelli, B., \& Marchioro, G. (2010). Teamwork: Effectively teaching an employability skill. Education \& Training, 52(6-7), 528-539. https://doi.org /10.1108/00400911011068478

Salas, E., DiazGranados, D., Klein, C., Burke, C. S., Stagl, K. C., Goodwin, G. F., \& Halpin, S. M. (2008). Does team training improve team performance? A meta-analysis. Human Factors, 50(6), 903-933. https://doi.org $/ 10.1518 / 001872008 X 375009$

Sandoval-Lucero, E. (2014). Serving the developmental and learning needs of the $21^{\text {st }}$ century diverse college student population: A review of the literature. Journal of Educational and Developmental Psychology, 4(2), 47-64.

Sundstrom, E. (1999). The challenges of supporting work team effectiveness. In E. Sundstrom (Ed.), Supporting Work Team Effectiveness (pp. 3-23). San Francisco: Jossey-Bass.

Tannenbaum, S. I., Mathieu, J. E., Salas, E., \& Cohen, D. (2012). Teams are changing: Are research and practice evolving fast enough? Industrial and Organizational Psychology: Perspectives on Science and Practice, 5(1), 2-24. https://doi.org/10.1111/j.1754-9434.2011.01396.x

Tata, J., \& Prasad, S. (2004). Team self-management, organizational structure, and judgments of team effectiveness. Journal of Managerial Studies, 16(2), 248-265.

Tinto, V. (2003). Learning better together: The impact of learning communities on student success. Higher Education Monograph Series, 1, 1.

van der Pol, J., van den Berg, B. A. M., Admiraal, W. F., \& Simons, P. R. J. (2008). The nature, reception, and use of online peer feedback in higher education. Computers \& Education, 51, 1804-1817. https://doi.org/10.1016/j.compedu.2008.06.001

Van der Vegt, G. S., de Jong, S. B., Bunderson, J. S., \& Molleman, E. (2010). Power assymetry and learning in teams: The moderating role of performance feedback. Organization Science, 21(2), 347-361. https://doi.org/10.1287/orsc. 1090.0452

Weiss, M., \& Hoegl, M. (2015). The history of teamwork's societal diffusion: A multi-method review. Small Group Research, 46(6), 589-622. https://doi.org/10.1177/1046496415602778

Werner, J. M., \& Lester, S. W. (2001). Applying a team effectiveness framework to the performance of student case teams. Human Resource Development Quarterly, 12(4), 385-402. https://doi.org/10.1002/hrdq.1004

White House, The. (n.d.). Education: Knowledge and skills for the jobs of the future. Retrieved January 9, 2017, from http://www.whitehouse.gov/issues/education/higher-education

Zaccaro, S. J., Ely, K., \& Shuffler, M. (2008). The leader's role in group learning. In V. I. Sessa \& M. London (Eds.), Work Group Learning (pp. 193-214). New York, NY: Lawrence Erlbaum. 


\section{Appendixes}

Appendix A: Conventional Team Member Evaluation Form

\begin{tabular}{lll}
\hline Competency & Definition & $\begin{array}{l}\text { Your } \\
\text { Evaluation }\end{array}$ \\
\hline Do the work & $\begin{array}{l}\text { Team members must "do the work" they are assigned outside of the team meeting to } \\
\text { support team success }\end{array}$ \\
\hline Show up & Team members must "show up" for meetings on time and ready to work \\
\hline Contribute & $\begin{array}{l}\text { Team members must "contribute" their ideas, knowledge, and expertise to the team } \\
\text { conversation }\end{array}$ \\
\hline Cooperate & $\begin{array}{l}\text { Team members must "cooperate" with team members by showing teammates respect, } \\
\text { listening well, and being open to feedback }\end{array}$
\end{tabular}

Note. Individuals evaluated each team member using the conventional team member evaluation form. For each competency, students were asked to provide a score (on a scale of $0 \%$ to $100 \%$ ) for each team member. The instructor then averaged the scores in each of the four categories that were assigned to them by their teammates and provided students with those average results.

Appendix B: Enhanced Team Member Evaluation Form

\begin{tabular}{llll}
\hline Competency & Poor Behavior & Good Behavior & Great Behavior \\
\hline \multirow{3}{*}{ Do the work } & Is not prepared & Defines task & Organizes work of others \\
& Doesn't do work & Understands goals & Ensures others are ready \\
& Poor quality & Work done on time & Follows up with teammates \\
& Minimal contribution & Well prepared & Volunteers help \\
\hline \multirow{5}{*}{ Show up } & Doesn't show up & Shows up for meeting & Sets meeting agenda \\
& Shows up late & Shows up on time & Leads process \\
& Unaware of time & Ready to work & Leads discussion \\
& Distracted at meeting & Uses time wisely & Holds other accountable \\
\hline \multirow{3}{*}{ Contribute } & Doesn't work on task & Participates & Motivates teammates \\
& Takes group off task & Shares information & Balances team and task \\
& Focus on own task & Focused on team & Integrates efforts \\
& Does not participate & Stays on task & Monitors progress \\
\hline \multirow{3}{*}{ Cooperate } & Dominates team & Listens to others & Involves others \\
& Is defensive & Open to feedback & Creates positive environment \\
& Does not listen & Respects team & Resolves differences \\
& Acts in self interest & Is flexible & Promotes functional conflict \\
\hline
\end{tabular}

Note. Individuals evaluated each of their team members on the 48 behaviors listed above. For each team member, the individual identified whether each of the 48 behaviors had been observed over the past two weeks in that team member. An average was taken across all team member evaluations and behaviorally specific feedback was provided.

\section{Copyrights}

Copyright for this article is retained by the author(s), with first publication rights granted to the journal.

This is an open-access article distributed under the terms and conditions of the Creative Commons Attribution license (http://creativecommons.org/licenses/by/4.0/). 